\title{
Diversity Analysis of Lactobacilli in Naturally Fermented Ethnic Goan Pork Sausages as Determined by PCR Amplification of 16-23S rRNA Intergenic Spacer Region
}

\author{
Solomon Rajkumar ${ }^{1 *}$, Renuka Nayar ${ }^{1}$, Susitha Rajkumar ${ }^{2}$, Dhananjay Desai ${ }^{2}$, \\ Kavitha Rajagopal ${ }^{1}$, Eaknath B. Chakurkar ${ }^{2}$, Magna Thomas ${ }^{3}$ and Muhasin Asaf ${ }^{4}$
}

${ }^{1}$ Department of Livestock Products Technology, ${ }^{3}$ Department of Dairy Science, ${ }^{4}$ Department of Animal Genetics and Breeding, College of Veterinary and Animal Sciences, Kerala

Veterinary and Animal Sciences University, Pookode, Lakkidi, Wayanad, India

${ }^{2}$ Animal Sciences Section, ICAR-Central Coastal Agricultural Research Institute, Ella, Old Goa, India

*Corresponding author

\section{A B S T R A C T}

\begin{tabular}{|l|}
\hline Ke y w o r d s \\
$\begin{array}{l}\text { Ethnic foods, } \\
\text { Lactobacillus, } \\
\text { Sausages, Microbial } \\
\text { diversity }\end{array}$ \\
\hline Article Info \\
\hline $\begin{array}{l}\text { Accepted: } \\
18 \text { November } 2020 \\
\text { Available Online: } \\
10 \text { December } 2020\end{array}$ \\
\hline
\end{tabular}

\section{Introduction}

Ethnic Goan pork sausages (Fig. 1) are deep red string of small sausages made from pork, toddy (coconut sap) vinegar, recheio masala (locally made with spices), and are extremely hot, spicy, and flavorful (Rosales, 2012). Goan sausages also called as chouricos are deep red pork sausages that are spicy and possess a characteristic flavour (Dilecta et al.,
The current study was conducted to study the diversity analysis of Lactobacilli in naturally fermented ethnic Goan pork sausages as determined by PCR amplification of 16-23S rRNA intergenic spacer region and optimal phylogenetic analysis. A total of 15 isolates were identified by the gene sequence analysis. Limosilactobacillus fermentum (60\%) Lactobacillus rhamnosus (6.66\%) and Lactobacillus brevis $(6.66 \%)$ were the predominant lactobacilli found in the Goan pork sausages. Phylogenetic analysis showed the clustering of the isolates and reference strains of the same species. The results obtained during this study will encompass the knowledge of lactobacillus species diversity during natural fermentation and ripening of Goan pork sausage. The lactobacilli found during the study could be responsible for the sensory attributes and antimicrobial functionality and further will pave the path for the Goan pork sausages as potential probiotic vehicles in the future. 
which fresh/frozen pork and Goan pork sausages contribute a major portion (Chakurkar et al., 2014).

Meat fermentation is as a complex phenomenon where microbial ecosystems in which bacteria, yeasts, and molds coexist (Franciosa et al., 2018). Fermented meat products have been produced and consumed for centuries which involves mixing of meats with salts, sugars, and seasoning followed by fermentation and drying processes (JuárezCastelán et al., 2019). Fermentation enhances the microbial stability and transforms highly perishable meat and fat into final products characterized by a defined sensory profile and aroma (Cocolin et al., 2011; Flores et al., 2004). Earlier researchers described microbial diversity of fermented meat products evidenced by the presence of several lactic acid bacteria (LAB) species belonging to different genera, but also strains of the same species during the fermentation process (Cocolin et al., 2011; Drosinos et al., 2005; Fontana et al., 2016; Rantsiou et al., 2005).

Several culture-dependent and cultureindependent techniques have been introduced for the identification of Lactobacilli population in fermented meat products. Application of molecular methods to directly detect DNA and RNA in microbial ecosystems became more practical and accurate in recent times as they save time and resources in comparison to traditional methods when plating or selective enrichments are used.

Further sequencing-based based methods were applied for the identification of microorganisms in meat products (De Filippis et al., 2013; Połka et al., 2015; Wang et al., 2018) and these sensitive and efficient methods allow the detection of low-number populations that may be lost during traditional culture methods (Cocolin et al., 2004).
Dilecta et al., (2019) carried out a study to elucidate the microbial counts with special emphasis on pathogenic bacteria from Goan pork sausages. However, to our knowledge, no previous studies were conducted on characterizing the lactobacilli by molecular approaches. Therefore, the current study was conducted to study the diversity analysis of Lactobacilli in naturally fermented ethnic Goan pork sausages as determined by PCR amplification of 16-23S rRNA intergenic spacer region. The results obtained during this study willen compass the knowledge of lactobacillus species diversity during natural fermentation and ripening of Goan pork sausage.

\section{Materials and Methods}

Sample collection and isolation of Lactobacillus spp

The Goan Pork sausage samples were collected from five different talukas (administrative blocks) of Goa (Fig. 2) where the Goan pork sausage production was predominant. Then samples were stored immediately after collection in a low temperature $\left(4^{\circ} \mathrm{C}\right)$ refrigerator aseptically to protect from contamination and deterioration. The Lactobacillus spp. was isolated from Goan pork sausages samples by method described by Islam et al., (2016). About $10 \mathrm{~g}$ of sausage was mixed with $90 \mathrm{ml}$ sterile saline and homogenized in stomacher and the homogenate was diluted in appropriate dilutions with $0.9 \%$ salt solution and inoculated in Man, Rogosa, and Sharpe (MRS) broth and MRS agar media (pH 6.5).

The plates were aerobically incubated at $37^{\circ} \mathrm{C}$ for $48 \mathrm{~h}$. Finally, the single colony of Lactobacillus was isolated by observing their colony morphology and some biochemical tests such as gram staining, catalase, and oxidase test. The well-isolated colonies were 
picked up and transferred to MRS broth for enrichment of Lactobacillus at $37^{\circ} \mathrm{C}$.

Identification of Lactobacilli spp. by bacteriological analysis: Identification was carried out according to the methods described by Bergey and Holt (1994). Without the use of anaerobic conditions, all strains grew well on MRS agar at $37^{\circ} \mathrm{C}$ for 48 $\mathrm{h}$ for selective outgrowth of Lactobacilli. From appropriate dilutions, one representative colony was picked and tentatively identified as Lactobacilli after Gram stain reaction, colony appearance, cell morphology, catalase test, oxidase test, indole test, methyl red test, Voges-Proskauer test, citrate utilization test and carbohydrate fermentation patterns as delineated byBergey and Holt (1994).

\section{Molecular identification of Lactobacillus spp.}

The isolates were further identified by molecular methods. The genomic DNA from $1 \mathrm{ml}$ of broth culture of Lactobacillus isolates and the control strain was extracted using DNeasy $®$ blood and tissue DNA extraction kit (Qiagen, Germany). Molecular identification was achieved by PCR amplification of the 16-23S rRNA intergenic spacer region in a PCR Thermocycler Pro (Eppendorf, Germany). Lactobacillus genusspecific primer corresponding to the flanking terminal sequence of the $16 \mathrm{~S}$ rRNA gene conserved in bacteria, including lactobacilli were selected. Primersets viz., LbLMA1-rev (5'-CTC AAA ACT AAA CAA AGT TTC$\left.3^{\prime}\right)$ and R16-1 (5'-CTT GTA CAC ACC GCC CGT CA-3') as described by Dubernet et al., (2002)were employed for DNA amplification. The standard Lactobacillus strain obtained from the ICAR-National Dairy Research Institute, Karnal (Haryana), India were used to standardize the PCR conditions. The PCR reaction mixture of $20 \mu \mathrm{L}$ was constituted with2X PCR master mix (Promega Gotaq green mastermix) $(10 \mu \mathrm{L})$, PCR water $(6 \mu \mathrm{L})$, and forward and reverse primers $(1 \mu \mathrm{L}$ each) and $2 \mu \mathrm{L}$ DNA. The PCR conditions were initial denaturation $\left(95^{\circ} \mathrm{C}\right.$ for $\left.5 \mathrm{~min}\right) ; 30$ cycles of denaturation $\left(95^{\circ} \mathrm{C}\right.$ for $\left.30 \mathrm{sec}\right)$; annealing $\left(55^{\circ} \mathrm{C}\right.$ for $\left.30 \mathrm{sec}\right)$; extension $\left(72^{\circ} \mathrm{C}\right.$ for $30 \mathrm{sec})$ and a final extension $\left(72^{\circ} \mathrm{C}\right.$ for 7 $\min )$.

The amplified PCR products obtained were subjected to gel electrophoresis (1\% agarose gels in TAE buffer; $\mathrm{pH}$ 8.2). Ethidium bromide $\left(5 \mu \mathrm{g} \mathrm{mL}{ }^{-1}\right)$ stained gels were visualized under UV transilluminator (BiometraGmBH, Germany). The PCR product was then purified by using the QIAquick® PCR purification kit (28105, Qiagen, Germany). The purified product was then quantified using the QuantiFluor ${ }^{\mathrm{TM}}-\mathrm{ST}$ system (E2670, Promega, USA). The PCR products were sequenced by Sangers sequencing at Eurofins Genomics India Pvt., Ltd. Bengaluru, India.

\section{Data analysis and evolutionary relationships of taxa}

The FASTA files of nucleotide sequences of the 16S rRNA gene of all the isolates were analyzed and identified using the BLASTN (Camacho et al., 2009) of the NCBI website (http//:www.ncbi.nlm.nih.gov/). The sequencing data obtained were submitted to the Sequence Read Archive of the NCBI (https://www.ncbi.nlm.nih.gov/) and have been assigned GenBank accession numbers MT786659 to MT786673.

Evolutionary relation among the Lactobacillus spp. sequences was done using MEGA X software (Kumar et al., 2018). ClustalW alignments were used to construct an optimal phylogenetic tree using the Neighbor-Joining method(N. Saitou, 1987)to infer evolutionary history. The percentage of replicate trees in which the associated taxa 
clustered together in the bootstrap test (1000 replicates) are shown next to the branches as described by Hillis and Bull (1993).

\section{Results and Discussion}

The PCR amplification of the 16-23S rRNA intergenic spacer region generated a product of size of approximately 232 bp in all 15 isolates, which indicates their belonging to the genus Lactobacillus. The nucleotide sequences of the 15 isolates were analyzed using a Neighbor-joining tree showing the phylogenetic relationships amongst the Lactobacillus spp. isolates from Goan pork sausage samples (Fig. 3). The evolutionary distances were computed using the Maximum Composite Likelihood method (Tamura, et $a l ., 2004$ )and were in the units of the number of base substitutions per site. All ambiguous positions were removed for each sequence pair (pairwise deletion option). Evolutionary analyses were conducted in MEGA X (Kumar et al., 2018).

The FASTA files were used as input to BLASTN (Camacho et al., 2009) utilizing a 16s microbial database downloaded from the National Centre for Biotechnology Information (NCBI) (ftp://ftp.ncbi.nlm.nih. gov/blast/db). As a norm to be included in the results, a match had to have greater than $98 \%$ identity with the query. Results from the BLASTN algorithm were parsed to keep only the first best match based on bit score. The number of matches to every organism detected within each sample were counted and used to determine the taxonomic level reached by comparing the most prevalent organism to the correct identity. The Lactobacillus species identified by sequence analysis in the present study are represented in Table 1.

Table.1 Different Lactobacillus species (\%) identified by sequence analysis in the present study along with the strain number and the NCBI accession number

\begin{tabular}{|c|c|c|c|c|}
\hline S. No & Lactobacillus species & Strain & NCBI accession no & n (\%) \\
\hline 1. & Limosilactobacillus fermentum & $\mathrm{R} 1$ & MT786659 & \multirow[t]{9}{*}{$9(60)$} \\
\hline 2. & Limosilactobacillus fermentum & R3b & MT786660 & \\
\hline 3. & Limosilactobacillus fermentum & R6.1 & MT786662 & \\
\hline 4. & Limosilactobacillus fermentum & R6.1L & MT786663 & \\
\hline 5. & Limosilactobacillus fermentum & R7.1 & MT786664 & \\
\hline 6. & Limosilactobacillus fermentum & R8.1 & MT786665 & \\
\hline 7. & Limosilactobacillus fermentum & R8.2 & MT786666 & \\
\hline 8. & Limosilactobacillus fermentum & R10.5 & MT786669 & \\
\hline 9. & Limosilactobacillus fermentum & R10.6 & MT786670 & \\
\hline 10. & Lactobacillus rhamnosus & $\mathrm{R} 4.1$ & MT786661 & $1(6.66)$ \\
\hline 11. & Lactobacillus spp. & $\mathrm{R} 10.2$ & MT786667 & \multirow{4}{*}{$\begin{array}{c}4 \\
(26.66)\end{array}$} \\
\hline 12. & Lactobacillus spp. & R10.4 & MT786668 & \\
\hline 13. & Lactobacillus spp. & R11.3 & MT786671 & \\
\hline 14. & Lactobacillus spp. & $\mathrm{R} 12.2$ & MT786672 & \\
\hline 15. & Lactobacillus brevis & $\mathrm{R} 12.4$ & MT786673 & $1(6.66)$ \\
\hline
\end{tabular}

The taxonomical genus Lactobacillus fermentum was emended and reclassified as Limosilactobacillus fermentum based on the polyphasic approach(Zheng et al., 2020) 
Fig.1 Rosary shaped deep red strings of ethnic Goan pork sausages, locally also called as "Choricos"

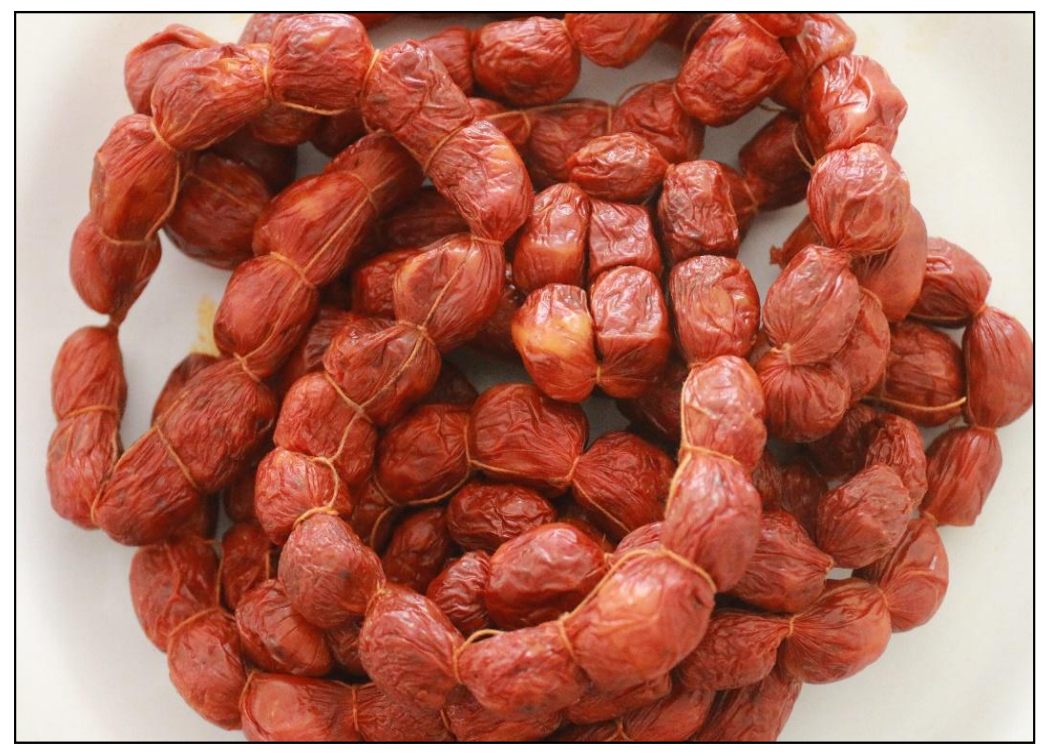

Fig.2 Map showing five different talukas (administrative blocks) of Goa (India) where the Goan pork sausage production is predominant

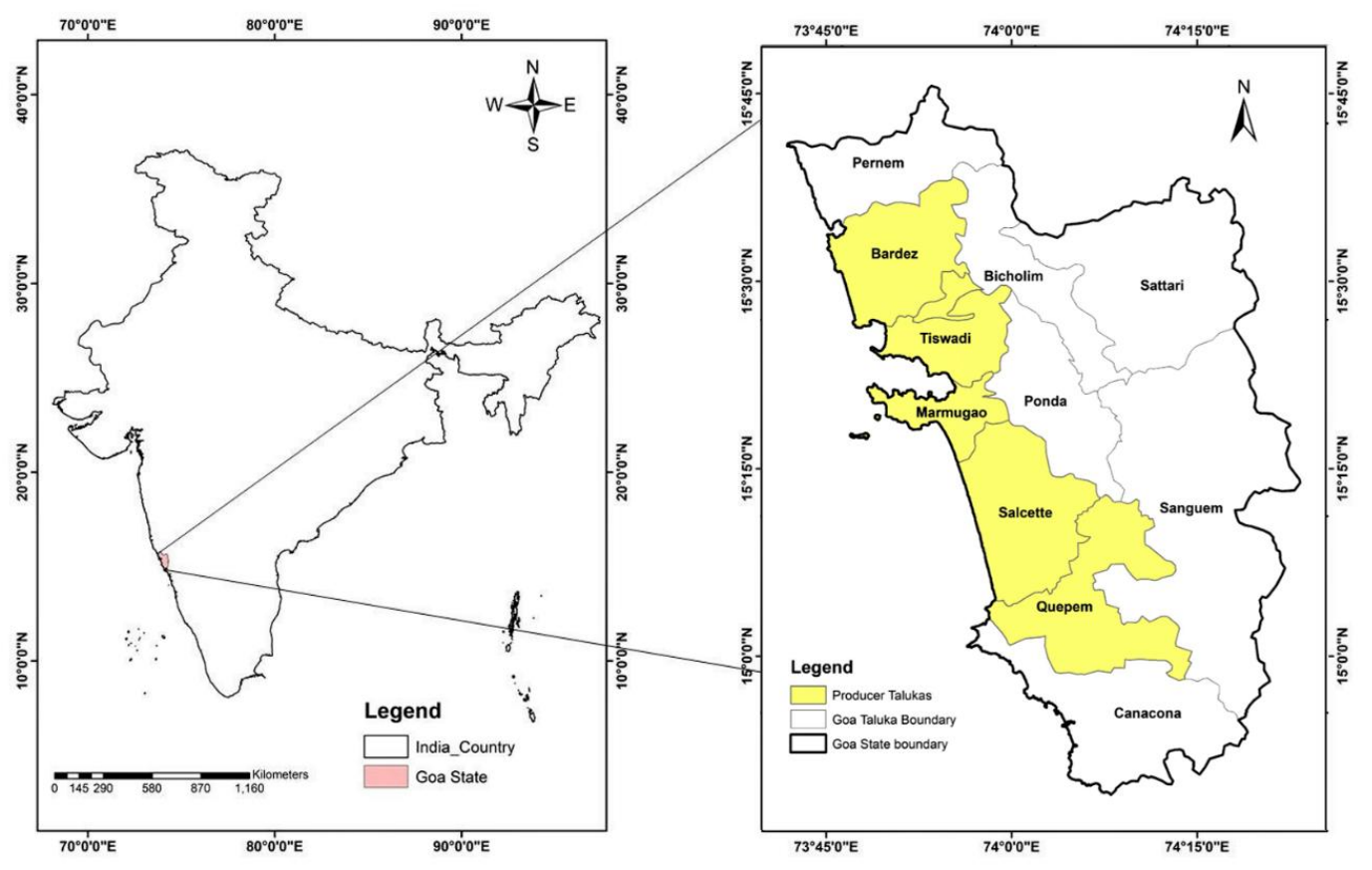


Fig.3 Neighbor-joining tree showing the phylogenetic relationships amongst the LAB isolates from Goan pork sausage samples and the type isolates of related genera based on 16S rRNA gene sequences. Bacillus (B.) subtilis was used as an outgroup.

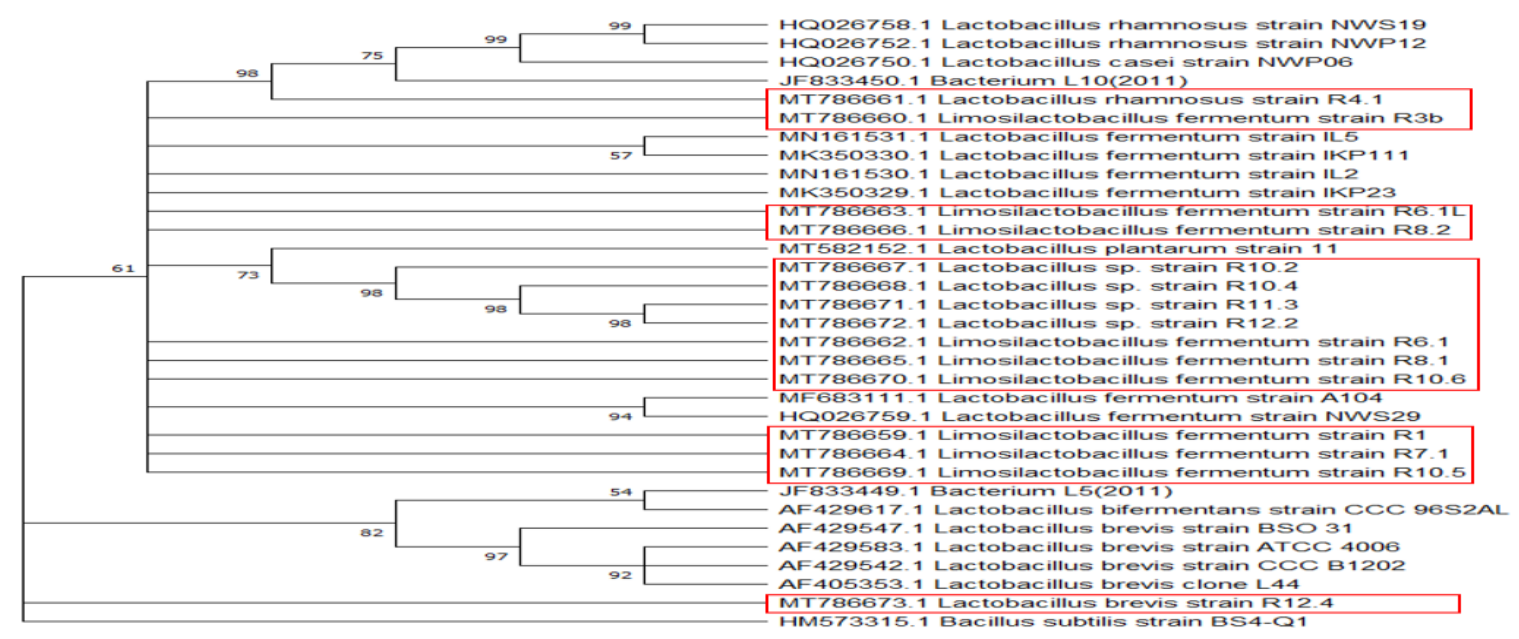

A total of 15 isolates were identified by the gene sequence analysis. Limosilactobacillus fermentum $(60 \%)$ was the predominant bacteria species followed by Lactobacillus rhamnosus (6.66\%), Lactobacillus brevis $(6.66 \%)$. Phylogenetic analysis showed the clustering of the isolates and reference strains of the same species. However, another four isolates (R10.2, 10.4, 11.3, and 12.2)appeared to be equally linked and formed into a single cluster indicating the $16 \mathrm{~S}$ rRNA gene sequences used were not discriminatory to species level for isolates in these groups. The taxonomical genus Lactobacillus fermentumwas emended and reclassified as Limosilactobacillus fermentum based on the polyphasic approach (Zheng et al., 2020).

Previous studies were conducted in dry fermented sausages (Comi et al., 2005; Coppola et al., 2000; Papamanoli et al., 2003; Urso et al., 2006), Spanish sausages (Aymerich et al., 2006), French dry sausages (Ammor and Mayo, 2007), Greek and Italian sausages (Comi et al., 2005; Drosinos et al., 2005; Tremonte et al., 2017) to characterize the Lactic acid bacteria species. The most frequently reported lactic acid bacteria (LAB) in earlier studies from fermented sausages are Lactobacillus sakei, Lactobacillus curvatus, Lactobacillus plantarum, Lactobacillus fermentum and Lactobacillus brevis (Hammes and Vogel, 1995; Schillinger et al., 1996). Nguyen et al., (2013) conducted similar gene sequence analysis studies on the diversity of the native LAB in nemchua(Vietnamese traditional meat product) and identified LAB associated with were identified as Lactobacillus pentosus, Lactobacillus plantarum, Lactobacillus brevis (5\%), Lactobacillus fermentum (0.7\%), Lactobacillus farciminis $(23 \%)$ were the predominant LAB. Further Limosilactobacillus fermentum (Lactobacillus fermentum) have been reported to be capable of converting $\mathrm{Mb}(\mathrm{Fe} 3+)$ to cured meat pigment $\mathrm{NO}-\mathrm{Mb}(\mathrm{Fe} 2+)$ in meat and meat products (Arihara et al., 1993; Zhang et al., 2007) and change the muscle color from brown to bright red. The possible bright red color of the Goan pork sausages could be attributed to the predominance of Limosilactobacillus 
fermentum. These Lactobacillus strains also reported to impart flavor (Henriksen and Stahnke, 1997; Toldrá et al., 1997) and exhibit some antimicrobial activity during sausage production (Rai et al., 2010). The presence of Lactobacillus strains further value to this type of meat products as a potential probiotic vehicle as indicated by Erkkilä et al., (2001) and Ruiz-Moyano et al., (2008).

In conclusion the adiversity of 15 isolates of Lactobacillus spp. was observed by PCR amplification of 16-23S rRNA intergenic spacer region in the naturally fermented Goan pork sausages. The predominant bacteria species Limosilactobacillus fermentum, Lactobacillus rhamnosus, and Lactobacillus brevis found during the study could be responsible for the sensory attributes, antimicrobial functionality, and potential probiotic vehicle.

\section{Acknowledgement}

Authors acknowledge the technical support given by Mrs. Archana Chandran (KVASU, Pookode), members of the doctoral students advisory committee of Kerala Veterinary and Animal Sciences University, Wayanad, Kerala, India

\section{Declaration of Interest statement}

The authors declare that they have no known competing financial interests or personal relationships that could have appeared to influence the work reported in this paper.

\section{References}

Ammor, M.S., and Mayo, B.2007. Selection criteria for lactic acid bacteria to be used as functional starter cultures in dry sausage production: An update. Meat Sci. 76 (1), 138-146.

Arihara, K., Kushida, H., Kondo, Y., Itoh, M., Luchansky, J.B., and Cassens, R.G.1993.
Conversion of metmyoglobin to bright red myoglobin derivatives by Chromobacterium violaceum, Kurthia sp., and Lactobacillus fermenturn JCM1173. J. Food Sci. 58 (1), $38-42$.

Aymerich, T., Martín, B., Garriga, M., VidalCarou, M.C., Bover-Cid, S., and Hugas, M. 2006. Safety properties and molecular strain typing of lactic acid bacteria from slightly fermented sausages. J. Appl. Microbiol. 100 (1), 40-49.

Bergey, D.H. and Holt, J.G., 1994. Bergey's Manual of Systematic Bacteriology. Wiliams Wiliams Eds., Balt. 787p.

Camacho, C., Coulouris, G., Avagyan, V., Ma, N., Papadopoulos, J., Bealer, K., and Madden, T.L.2009. BLAST+: architecture and applications. BMC Bioinformatics. 10 (1), 421.

Chakurkar, E.B., Naik, P.K., Swain, B.K and Singh, N.P. 2014. Performance of Crossbred Pigs Reared Under Traditional and Scientific Feeding Practices in Goa. Anim. Nutri and Feed Technol. 14 (2), 405-409.

Cocolin, L., Dolci, P., and Rantsiou, K.2011. Biodiversity and dynamics of meat fermentations: the contribution of molecular methods for a better comprehension of a complex ecosystem. Meat Sci. 89 (3), 296302.

Comi, G., Urso, R., Iacumin, L., Rantsiou, K., Cattaneo, P., Cantoni, C., and Cocolin, L. 2005. Characterisation of naturally fermented sausages produced in the North East of Italy. Meat Sci. 69 (3), 381-392.

Coppola, S., Mauriello, G., Aponte, M., Moschetti, G., and Villani, F.2000. Microbial succession during ripening of Naples-type salami, a southern Italian fermented sausage. Meat Sci.56(4),321-329.

De Filippis, F., La Storia, A., Villani, F., Ercolini, D., 2013. Exploring the sources of bacterial spoilers in beefsteaks by cultureindependent high-throughput sequencing. PLoS One. 8 (7), 70222.

Dilecta, D., Parab, A., Insha, D., Patil, G., and Silveira, V., 2019. Microbiota of goan sausages. J. Meat Sci. 14 (1), 50-54.

Drosinos, E.H., Mataragas, M., Xiraphi, N., 
Moschonas, G., Gaitis, F., and Metaxopoulos, J. 2005. Characterization of the microbial flora from a traditional Greek fermented sausage. Meat Sci. 69(2), 307317.

Dubernet, S., Desmasures, N., and Guéguen, M.2002. A PCR-based method for identification of lactobacilli at the genus level. FEMS Microbiol. Lett. 214 (2), 271275.

Erkkilä, S., Suihko, M.-L., Eerola, S., Petäjä, E. and Mattila-Sandholm, T.2001. Dry sausage fermented by Lactobacillus rhamnosus strains. Int. J. Food Microbiol. 64 (1-2), 205-210.

Flores, M., Durá, M.-A., Marco, A., and Toldrá, F.2004. Effect of Debaryomyces spp. on aroma formation and sensory quality of dryfermented sausages. Meat Sci. 68 (3), 439446.

Fontana, C., Bassi, D., López, C., Pisacane, V., Otero, M.C., Puglisi, E., Rebecchi, A., Cocconcelli, P.S. and Vignolo, G.2016. Microbial ecology involved in the ripening of naturally fermented llama meat sausages. A focus on lactobacilli diversity. Int. J. Food Microbiol. 236 (1), 17-25.

Franciosa, I., Alessandria, V., Dolci, P., Rantsiou, K. and Cocolin, L.2018. Sausage fermentation and starter cultures in the era of molecular biology methods. Int. J. Food Microbiol. 279 (1), 26-32.

Hammes, W.P., and Vogel, R.F.1995. The genus lactobacillus. In: The Genera of Lactic Acid Bacteria. Springer, pp. 19-54.

Henriksen, A.P., and Stahnke, L.H.1997. Sensory and chromatographic evaluations of water soluble fractions from dried sausages. J. Agric. Food Chem. 45 (7), 2679-2684.

Hillis, D.M. and Bull, J.J.1993. An Empirical Test of Bootstrapping as a Method for Assessing Confidence in Phylogenetic Analysis. Syst. Biol.42(2),182-192.

Islam, K.N., Akbar, T., Akther, F., and Islam, N.N.2016. Characterization and Confirmation of Lactobacillus spp. from Selective Regional Yoghurts for Probiotic and Interference with Pathogenic Bacterial Growth. Asian J. Biol. Sci. 9(1), 1-9.
Juárez-Castelán, C., García-Cano, I., EscobarZepeda, A., Azaola-Espinosa, A., ÁlvarezCisneros, Y., and Ponce-Alquicira, E.2019. Evaluation of the bacterial diversity of Spanish-type chorizo during the ripening process using high-throughput sequencing and physicochemical characterization. Meat Sci. 150 (1), 7-13.

Kumar, S., Stecher, G., Li, M., Knyaz, C., and Tamura, K. 2018. MEGA X: molecular evolutionary genetics analysis across computing platforms. Mol. Biol. Evol. 35 (6), 1547-1549.

N. Saitou, 1987. The neighbor-joining method: a new method for reconstructing phylogenetic trees. The neighbor-joining method: a new method for reconstructing phylogenetic trees. Molecular Biology and Evolution. 4(4), 406. https://doi.org/10.1093/ oxfordjournals.molbev.a040454. Mol. Biol. Evol.

Nguyen, D.T.L., Van Hoorde, K., Cnockaert, M., De Brandt, E., De Bruyne, K., Le, B.T., and Vandamme, P. 2013. A culture-dependent and-independent approach for the identification of lactic acid bacteria associated with the production of nem chua, a Vietnamese fermented meat product. Food Res. Int. 50 (1), 232-240.

Papamanoli, E., Tzanetakis, N., LitopoulouTzanetaki, E. and Kotzekidou, P., 2003. Characterization of lactic acid bacteria isolated from a Greek dry-fermented sausage in respect of their technological and probiotic properties. Meat Sci.65(2),859867.

Połka, J., Rebecchi, A., Pisacane, V., Morelli, L., and Puglisi, E.2015. Bacterial diversity in typical Italian salami at different ripening stages as revealed by high-throughput sequencing of 16S rRNA amplicons. Food Microbiol. 46 (1), 342-356.

Rai, A.K., Tamang, J.P., Palni, U., 2010. Microbiological studies of ethnic meat products of the Eastern Himalayas. Meat Sci. 85 (3), 560-567.

Rantsiou, K., Urso, R., Iacumin, L., Cantoni, C., Cattaneo, P., Comi, G., and Cocolin, L.2005. Culture-dependent and 
independent methods to investigate the microbial ecology of Italian fermented sausages. Appl. Environ. Microbiol.71(4), 1977-1986

Rosales, M.V.2012. My umbilical cord to Goa: food, colonialism and transnational Goan life experiences. Food Foodways 20 (3-4), 233-256.

Ruiz-Moyano, S., Martín, A., Benito, M.J., Nevado, F.P., and De Guía Córdoba, M., 2008. Screening of lactic acid bacteria and bifidobacteria for potential probiotic use in Iberian dry fermented sausages. Meat Sci. 80 (3), 715-721.

Schillinger, U., Geisen, R., and Holzapfel, W.H.1996. Potential of antagonistic microorganisms and bacteriocins for the biological preservation of foods. Trends Food Sci. Technol. 7 (5), 158-164.

Tamura K, Nei M and Kumar S. 2004. Prospects for inferring very large phylogenies by using the neighbor-joining method. Proc. Natl. Acad. Sci. U. S. A.

Toldrá, F., Flores, M., and Sanz, Y.1997. Drycured ham flavour: enzymatic generation and process influence. Food Chem. 59 (4), 523-530.

Tremonte, P., Sorrentino, E., Pannella, G., Tipaldi, L., Sturchio, M., Masucci, A., Maiuro, L., Coppola, R., and Succi, M., 2017. Detection of different microenvironments and Lactobacillus sakei biotypes in Ventricina, a traditional fermented sausage from central Italy. Int. J. Food Microbiol. 242, 132-140.

Urso, R., Comi, G., and Cocolin, L.2006. Ecology of lactic acid bacteria in Italian fermented sausages: isolation, identification and molecular characterization. Syst. Appl. Microbiol. 29 (8), 671-680.

Wang, X., Zhang, Y., Ren, H., and Zhan, Y., 2018. Comparison of bacterial diversity profiles and microbial safety assessment of salami, Chinese dry-cured sausage and Chinese smoked-cured sausage by highthroughput sequencing. LWT 90, 108-115.

Zhang, X., Kong, B., Xiong, Y.L., 2007. Production of cured meat color in nitritefree Harbin red sausage by Lactobacillus fermentum fermentation. Meat Sci. 77 (4), 593-598.

Zheng, J., Wittouck, S., Salvetti, E., Franz, C.M.A.P., Harris, H.M.B., Mattarelli, P., O'Toole, P.W., Pot, B., Vandamme, P., Walter, J., 2020. A taxonomic note on the genus Lactobacillus: Description of 23 novel genera, emended description of the genus Lactobacillus Beijerinck 1901, and union of Lactobacillaceae and Leuconostocaceae. Int. J. Syst. Evol. Microbiol. 70 (4), 2782-2858.

\section{How to cite this article:}

Solomon Rajkumar, Renuka Nayar, Susitha Rajkumar, Dhananjay Desai, Kavitha Rajagopal, Eaknath B. Chakurkar, Magna Thomas and Muhasin Asaf. 2020. Diversity Analysis of Lactobacilli in Naturally Fermented Ethnic Goan Pork Sausages as Determined by PCR Amplification of 16-23S rRNA Intergenic Spacer Region. Int.J.Curr.Microbiol.App.Sci. 9(12): 2789-2797. doi: https://doi.org/10.20546/ijcmas.2020.912.333 